\title{
Employment Experiences of Visible Minority Immigrant Women: A Literature Review
}

\author{
Bharati Sethi ${ }^{1, *}$ and Allison Williams ${ }^{2}$
}

${ }^{1}$ Assistant Professor King's School of Social Work, Western University, London, Ontario, N6A 2M3, Canada

${ }^{2}$ CIHR Research Chair in Gender, Work \& Health, Professor, School of Geography and Earth Sciences, McMaster University, 1280 Main Street West, Hamilton, ON L8S 4K1, Canada

\begin{abstract}
This literature review provides an overview of the employment experiences of visible minority immigrant women based on a critical review of the international English language peer-reviewed publications from 1980 to 2011. The overall goal of the review was to raise awareness and understanding of immigrant women's employment experiences, health experiences, and the link between employment and health for this subpopulation. Approximately 126 papers articles were analysed. The key findings specific to women's employment experiences are: 1) Economic welfare of immigrants continues to deteriorate with post-2000 arrivals to Canada facing much more occupational downward mobility than their 1990's cohort; 2) Gender, ethnicity and immigrant status intersect to shape visible minority women's employment experiences of deskilling, discrimination, and marginalization; 3) Collaboration is required with all three levels of government (federal, provincial, and municipal) employers, educational institutions, and community agencies to foster immigrant visible minority women's economic integration in Canadian society.
\end{abstract}

Keywords: Literature review, Employment, Visible minority women, Immigrant, Health.

\section{INTRODUCTION}

In the last decade the Canadian government has broadened its immigration policy in attempts to attract skilled labour, populate Canada, expand its domestic market and develop the country's resources. The replacement of 'race based' with 'skill based' selection criterion in the immigrant recruitment process has led to the increase in migration from non-European countries. National statistics indicate that in Canada 5.1 million belong to the visible minority population. Of these 2.6 million (51\%) are women (Chui \& Maheux, 2011). Furthermore, in 2006, visible minority women comprised $16.4 \%$ of the total female population in Canada (Chui \& Maheux, 2011). These statistics demonstrate that migration is no longer purely a male phenomenon as it was once at the onset. Nonetheless, an analysis of the current immigration policies provide evidence that these policies continue to be oppressive to immigrant women, often putting them in a disadvantaged position in Canadian society (OxmanMartinez, Hanley, Lach, Khanlou, Weerasinghe, \& Agnew, 2005). Furthermore, the Canadian occupational entry policies demand a high level of education, work experience, knowledge of official language(s) and employment experience from immigrants. The exclusive focus on 'paid employment' and the non-recognition of women's human and/or social capital obtained abroad renders their work within

*Address correspondence to this author at the King's School of Social Work, Western University, London, Ontario, N6A 2M3, Canada; Tel: 1-519-433-3491 Ext. 4553; Fax: 1-519-433-8691; E-mail: bsethi3@uwo.ca the private sphere as 'unproductive', deskills them, and relegates them to the status of 'dependants' in Canadian society (Iredale, 2005). Even though many of the recent female migrants are professional and educated women, six months after their arrival, only $32 \%$ of the women in the family class were employed, compared with $54 \%$ of men (A Commitment to Training and Employment for Women [ACTEW], 2008). For cultural reasons, women often delay validating their own credentials until the husband is established in the labour market (Iredale, 2005; Ralston, 1999). While gender is a significant factor that contributes to more women than men occupying precarious employment status (such as part-timework), visible minority women ${ }^{1}$ $(56 \%)$ are more likely to work part-time than non-visible minority women (Chui \& Maheux, 2011), highlighting the contribution of race in the employment status. Even so, the occupational profile of visible minority women and non-visible minority women is similar; both these groups are mainly employed in traditional female sectors. It is worth noting that at the intersection of gender and culture, "visible minority women were less likely than their non-visible minority counterparts to be employed in jobs related to social science, education, government service and religion; art, culture, recreation and sport; management; and business, finance and

\footnotetext{
${ }^{1}$ Visible minorities are defined under the Employment Equity Act as 'persons, other than Aboriginal persons, who are non-Caucasian in race or non-white in colour' (Chui \& Maheux, 2011, p. 38). These include the following groups: Chinese, South Asians, Blacks, Arabs, West Asians, Filipinos, Southeast Asians, Latin Americans, Japanese, Koreans, and other visible minority groups such as Pacific Islanders.
} 
administration" (Chui \& Maheux, 2011, p.30). As more visible minority women continue to occupy labour market positions to fulfill Canada's skilled labour shortage, understanding their employment experiences is necessary to facilitate both their economic and health integration. This is especially the case given the growing percentage of the established Canadian population reaching retirement age. Even though the emphasis of this review is Canada, a few important studies from outside Canada are included for comparative sake.

\section{RESEARCH METHODS}

The literature review was guided by the following overarching question: What are the employment experiences of immigrant visible minority women?

\subsection{Search Strategy and Data Sources}

This literature review provides an overview of the employment experiences of visible minority immigrant women based on a critical review of international, English language, peer-reviewed academic papers, published between 1980 to 2011. The search was conducted over a 6-month period in 2011, beginning in January 2011. Four data sources were explored for articles written in English. All accounts of employment and health published in English since 1980 were identified (some data bases did not have information available prior to 1985). The review examined how scholarship on immigration has changed with evolving immigration policy and, in so doing, informed practice, policy and research. The search produced 2153 study abstracts and 12 books. Articles that were not relevant to the topic of employment and/or health of immigrant visible minority women were eliminated. In order to best screen the articles, the following key word combinations were used: racialized women OR immigrant women OR refugee women OR women of colour/visible minority women as participants AND/OR employment AND/OR health. The total number of papers reviewed were 242 .

For the final screening process, the evaluation criteria of Westhues et al.'s (2008) was adapted. The authors used a Likert type scale to rate articles based on its relevance to the topic. Based on Westhues et als. (2008) evaluation criteria, the 242 articles were ranked using a 5-star scale, ranging from not relevant to highly relevant in providing information on the employment and/or health experiences of visible minority women. A one-star article met none of these criteria; and two- to three-star articles met the criteria to some extent. The one-star articles were excluded. The two- to three-star articles were read again and included if they contributed to the relevant information on employment and/or health experiences of visible minority women. Four- and five-star articles were automatically included in the final selection of studies for the literature review. The final selection included about 126 papers that provided information on employment and/or health experiences of visible minority immigrant women. Below we present limited findings from the employment review.

\section{LITERATURE REVIEW FINDINGS}

A substantial body of literature on the employment experiences of immigrants in Canada (e.g. Aydemir \& Skuterud, 2005; Bauder, 2003; Bloom, Grenier, \& Gunderson, 1994; Houle \& Yssaad, 2010; Li, 2001; Pendakur \& Pendakur, 1998, 2002; Picot, Hou, \& Coulombe, 2007; Reitz, 2001; Wald \& Fang, 2008); United States (e.g. Borjas, 1987, 2003; Chiswick, 1978; Hum \& Simpson, 2010); and Australia (e.g. Cobb- Clark \& Crossley, 2001; Evans \& Bowlby, 2000) - all countries with similar skills-based selection criteria for immigrants - was found to be mainly quantitative in nature and focused on the objective predictors of economic success, namely, trends in earning and employment. In recent years, literature examining subjective predictors (such as discrimination) of immigrant economic success has emerged predominantly from qualitative work (see Saraswati, 2000; Schmidt, 2010; Pio, 2005; Man, 2004).

The key findings from the literature review are divided into two parts: 1. Key themes from large-scale studies (quantative studies using national surveys and census) and; 2. Key themes from small scale studies (mixed-method studies and qualitative papers). The results from small-scale studies were useful in elaborating on the evidence from the large-scale quantitative work.

\subsection{Key Themes for Large-Scale Studies}

The following discussions are framed around key themes common to all or most of the papers reviewed from large scale studies:

\subsubsection{Economic Welfare of Immigrants}

There is now a consensus amongst researchers that the labour market outcomes among immigrants entering from the 1980's have continued to deteriorate with post-2000 arrivals facing much more occupational 
downward mobility than their previous cohort in the 1990's. Following the seminal work of Borjas (1990) on immigrant wages, a proliferation of research emerged in Canada primarily aimed at calculating the earnings difference between immigrants (European and nonEuropeans) and their Canadian-born counterparts (European and non-Europeans) (see for example, Bloom, Garnier \& Gunderson, 1994; and Pendakur \& Pendakur, 1998; Reitz, 2001). Post-2000 studies suggest that the gap between immigrants and the Canadian-born population is widening (Bauder, 2003; Banerjee, 2009; Gilmore, 2008; Houle \& Yssaad, 2010; Li, 2001; Picot et al., 2007; Reitz, 2007a; Wald \& Fang, 2008). This economic deterioration is worse for members of visible minority groups (Aydemir \& Skuterud, 2005; Banerjee, 2009; Gilmore, 2008; Li, 2001; Liu, 2006; Reitz, 2001).

\subsubsection{Gender Gaps in Wages}

To identify earnings disadvantage specifically related to visible minority population, researchers use a visible minority indicator. This indicator was included for the first time in the Canadian Census public use database in 1996. The formation of the 1986 Employment Equity Act enforced the need to collect data based on a group's visibility status, race or colour (Reitz, 2001; Stelener, 2000). Much of the earlier analysis was restricted to Europeans, Blacks, Chinese, and Aboriginals.In additon, earlier studies exclusively focused on men as the small sample size did not allow for gender-based comparison between men and women. The increasing labour market attachment of women motivated researchers to examine the gender earnings gap. Such gender-specific investigation is important, "to ensure that analysis of institutional change takes account of the changing labour market status of women" (Reitz, 2001, p. 588).Gender-based analysis (GBA) of employment rates for immigrant women found that in $2001,63 \%$ of all visible minority women (foreign born and Canadian-born) aged 25 to 64 were active in the labour force compared with $70 \%$ of non-visible minority women and $79 \%$ visible minority men in the same age range (Statistics Canada, 2006).

In their influential Canada-wide study covering Halifax, Montreal, Ottawa, Toronto, Winnipeg, Calgary, Edmonton, and Vancouver, Pendakur \& Pendakur (2002) describe the period between 1986 to 1996 as "losing ground" (p.498) for Canadian-born visible minority women. They analysed Canadian Census PUMF's from 1971 through 1996 and after controlling for personal characteristics of the workers (such as age, schooling, marital status, household size, and language) found that, except for Vancouver, minority women's earnings dropped significantly compared to white women. They write: "Overall, for non-white women, the period 1981 through to 1996 has been one of worsening relative earnings outcomes" (p. 498). For instance, from 1986 to 1996 the negative earnings differential experienced by visible minority women in Halifax, Montreal, and Toronto, in comparison to white women with identical personal characteristics, was 15 $\%, 19 \%$ and $10 \%$ respectively. It seems that labour market discrimination is higher for women who are foreign-born and of visible minority status (being nonwhite). Other studies report that labor market discrimination may be higher for immigrant visible minority women when compared to Canadian-born visible minority women (Browne \& Misra; 2003; Gilmore, 2008; Pendakur \& Pendakur, 2002; Reitz 2001).

\subsection{Causes of Poor Economic Welfare of Recent Immigrants}

Research aimed at determining the general downward trend in immigrant labour market performance points to the following factors.

\subsubsection{Shift in the Immigrant Source Country}

Aydemir \& Skuterud's (2005) analysis of the Canadian Census PUMF's from 1966 through to 2000 found that "the compositional shifts in region of birth across immigrant cohorts" played a major role in reducing the earnings of both immigrant men and women (p. 656). The authors note that the greatest decline occured from the 1980's, a period when the points regime shifted immigration from European to non-European regions. Looking specifically at female immigrants, these authorsobserved that between 1960 to the 1990's, as the numbers of immigrant women from Asia, Latin America, Africa and the Caribbean continued to rise, there was simultaneously a deteoriatation in earnings of this cohort compared to the previous cohorts from mainly European regions. Even in the 1990's, a time of a booming Canadian economy, this trend in earnings continued even though non-European immigrant women entering Canada were more educated than were the previous cohort of European immigrant women. Some studies attribute immigrants' country of origin as a cause of decline in immigrant income (Bloom et al., 1994; Foroutan, 2008; Reitz, 2001, 2007a, 2007b). Reitz \& Banerjee (2007 argue that racial inequality and discrimination (such as discounting of immigrant educational credentials) is 
implicated in immigrants' lower earnings and higher poverty rates as compared to the rest of the Canadian population; while both white and visible minority immigrant groups experience inequality, the experience of inequality is higher for visible minorities.

\subsubsection{Language Barriers}

In the afore-mentioned study, Aydemir \& Skuterud (2005) attributed approximately one-third of the deteriorating immigrant earning to the combined effect of country of origin and language ability, of which a smaller percentage was associated with having a mother tongue other than English or French. Conversely, in the Longitudinal Survey of Immigrants to Canada (LSIC), language emerged as the primary obstacle to employment integration of immigrant men and women (Grondin, 2005). Even though it is now recognized that "language is one of the most important determinants of the speed and quality of labour market adjustment among entering immigrants to any culture" (Picot \& Sweetman, 2011, p. 12), the relationship between language fluency and finding a job that matches immigrants' skills and educationare less clear (Grondin, 2007). For example, Grondin (2007) observes:

It is always possible that the language level is not directly related to whether the respondent has an appropriate job. It may be that the relationship is indirect and that the effect observed is instead due to another characteristic of the respondent that is strongly related to the language level (for example, motivation, personality, network of contacts, etc.). ( p. 51)

Thus, it is possible that while language training helps immigrants adapt to life in Canada, it does not necessarily help them gain recognition of their human capital skills (such as education and work skills) obtained in their country of origin (Grondin, 2005, Sethi, 2009).

\subsubsection{Non-Recognition or De-Valuation of Immigrant Education and Work Experiences}

The foreign accreditation issue comes alive in stories we hear of doctors from India doing manual labour and skilled women from the Philippines working as domestic labourers. Reitz (2001) defines skill underutilization as "any employment of immigrants in work below a level of skill at which they could function as effectively as native-born Canadians" (Reitz, 2001, p. 351). While Canadian-born men and women may also experience discounting of their skills, visible minority groups often lack Canadian experience and the discounting of foreign credentials, both which appear to be major determinants that affect their prospects in the labour market (Houle \& Yssaad, 2010; Reitz, 2001; Buhr, 2010; Picot \& Sweetman, 2011; Li, 2001; Houle \& Yssaad, 2010). Aydemir \& Skuterud (2005) refute the popular notion that foreign education can be attributed to the decline in immigrants' income. Nonetheless, their study does reveal that foreign experience has an adverse effect on male and female earnings.

In another study, Buhr (2010) examined the link between foreign credentials and wages for a specific population: immigrant nurses. She found that all nurses who were educated outsideCanada received a wage penalty relative to Canadian-born nurses. Nurses educated in Africa and the Caribbean faced the highest wage penalty of $13 \%$. European and U.S. educated nurses experienced a wage penalty of 6 to $9 \%$ while those educated in Australia experienced the lowest wage penalty of $4 \%$.

Li's ( 2001) study made an important contribution to the subject of foreign credentials in demonstrating the effect of gender on the value of foreign credentials. His results from the Canadian Census suggest that foreign credentials accounted for half of the income disparity between Canadian-born degree holders and immigrant visible minority degree holders. Further, gender interacted with visible minority status and immigrant status to create multiple negative effects in earnings for foreign-born visible minority women. Such multiple effects are increasingly being framed under the Double or Triple Jeopardy hypothesis or Disadvantage. The author concludes, "For all types of degree-holders, white men had the highest earning level, followed by visible-minority men who had an advantage over nonvisible-minority women, as well as visible-minority women" (p. 32).

\subsubsection{Double or Triple Jeopardy/Disadvantage}

De Jong \& Madamba (2001) tested the 'Double Disadvantage' economic hypothesis to examine its effect on underemployment in the United States (refers to a mismatch of job versus immigrant skills and education). Overall, the authors found under employment among females was greater than that of males (similar to Li's, 2001 results) and higher for immigrants than those American-born. Within the visible minority groups, the greatest mismatch was seen amongst Asians as compared to Blacks and Hispanics. The authors explain that the double 
disadvantage effect of minority status and immigration status proved true only for Asian immigrant men and women. Furthermore, Asian immigrant women were most likely to be unemployed, underemployed, and to experience poverty even after controlling for education, language, age, and work experience. These authors offer three possible explanations for the double disadvantage of Asian immigrant females: One, lower levels of labour market integration of Asian immigrant females as compared to their native born counterparts. It is also possible that native- born Asian female have higher level of integration compared to other minority groups. Two, Asian immigrant women especially those who are new to Canada demonstrate "culture bound' characterstics such as staying at home and keeping house and being shy and less aggressive" thus, they have low labour market attachment that increases their risk of underemployment (p. 127). Three, Asian females may be employed in ethnic enclaves or working in family business.

\subsubsection{Employment Discrimination}

Refers to "a negative employment decision based on statuses such as a birthplace or origins, rather than based solely on credentials and qualifications directly related to the potential productivity of the employee" (Reitz, 2001, p. 353). While employment discrimination is difficult to prove, more studies are needed to provide evidence of its existence. Oreopoulos' (2009) field experiment with 6,000 resumes produced some shocking results. He reported that resumes with English-sounding names were $40 \%$ more likely to receive a call back for an interview compared to resumes with Indian, Chinese or Pakistani names, even when the two resumes listed similar Canadian experience and education. Call back rates that listed foreign experience from India, China or Pakistan was $8.8 \%$ compared to $15.8 \%$ for Canadian foreign experience and $14.1 \%$ for British foreign education. Call back rates did not differ significantly by gender. Similar to male applicants, English sounding female names were favoured. The author specultates that it is possible that employers could not distinguish gender in foreign sounding names. It is indeed disturbing, that the "applicant's name matters considerably more than his additional education, multiple language skills, and extracurricular activities" in employers' hiring decisions (Oreopoulos, 2009, p. 26).

\subsection{Key Themes from Small Scale Studies}

The following section highlights the main themes from small scale mixed-method studies and qualitative papers.

\subsubsection{Discrimination}

Scholars who have written on minority immigrant/refugee women's employment experiences agree that discrimination is the most pervasive barrier to women's ability to: find paid work; be promoted, and; experience job satisfaction. Immigrant women were discriminated on the basis of individual characteristics such as gender (e.g., Saraswati, 2000; Espiritu, 1999); dress (e.g., Schmidt, 2010); accent (e.g., Schmidt, 2010; Pio, 2005; Syed \& Pio, 2010); age (e.g. Schmidt, 2010; Guo, 2010), and/or; culture, race, or religion (e.g. , Evans \& Bowlby, 2000; Man, 2004; Pio, 2005; Syed \& Pio, 2010). Others experienced systemic discrimination based on their immigration status (Man, 2004; Schmidt, 2010; Saraswati, 2000); foreign accreditation (e.g., Man, 2004; Raghuram \& Koffman, 2004; Shahrzad, 1999; Zaman, 2010) and; pressure to conform to the Western work culture and policies, such as dress codes and teaching styles (e.g., Pio, 2005; Evans \& Bowlby, 2000).

In Mahtani's (2004) study with visible minority women (faculty and students) in the North American and British academy, accounts of racial and gendered barriers filled the pages of the questionnaires. It is paradoxical, this author contends that "while scholarship in geography has been revitalized by its engagement with issues of diversity and difference, our policies and practices within geography departments continue to reflect a pervasive persistence of women of colour and gendered inequities in the workplace"( $p$. 91). The subject of 'being out of place' amongst the dominant white academy was frequently cited in this study. Mahtani suggests that the paucity of visible minority women (12\% in 2002) in Canadian faculty makes it difficult for them to negotiate hegemonic academic policies/ practices.

From an immigration policy standpoint, Schmidt's (2010) study deserves special attention. Her qualitative ethnography research examined the issues affecting immigrant teachers (European and visible minority) in Manitoba elementary schools. Her interviews and focus groups with immigrant women and members of the education-stakeholder community found that even after immigrant women attained their professional accreditation to teach in Canada, they continued to face employment instability, were unable to find fulltime employment, and worked for low wages. The school staff treated participants who were working under the provincial nominee program as exchange students rather than as colleagues. While European 
and non-European teachers were perceived as foreigners as a result of their immigration status, nonEuropean women were discriminated against based on dress and perceived language proficiency. Employers were reluctant to invest in their training or promote them due to their temporary visa status. From an economic standpoint, Schmidt (2010) purposefully argues that it is critical for employers to be educated about the benefits of hiring foreign trained professionals from diverse countries. It is possible that once employers can access the quality of immigrant education or work experiences they would regard immigrant woman as a 'worthy investment'. His interviews with government officials suggested that there was an abundance of teachers in Manitoba. Employers were, thus, more likely to hire young graduates from Canadian institutions rather than spend time and energy in training foreign workers, regardless of their years of experience and specialized skills that they bring to the workforce. Schmidt argues that not hiring immigrant teachers because they are overqualified (have superior qualifications) is a form of discrimination "that marginalizes immigrant teachers and excludes them from the Manitoba education system" (p.249).

Interestingly, Moras' (2010) interviews with white United States-born women uncovered colour-blind discourses in paid domestic work and illustrated how 'language', 'immigration' and 'culture' are subtly used today as racial markers rather than an overt display of racial preferences. In this study, white women hired women of visible minority groups to clean their houses and paid them by the house rather than the customary payment by the hour. Some of the negotiations were strictly by 'cash' and undocumented. Aside from the risk of increased abuse and marginalization of these workers, such practices have serious economic implications. Such practices also problematize the notion of belonging (who has the right to belong) and citizenship. Moras, (2010) asserts that "being undocumented undermines women's agency and exacerbates the exploitive conditions of paid domestic work" (p. 251). Interesting, white employers reiterated that 'colour' or 'race' were not implicated in the hiring decisions, though English ability did matter. Further, employers failed to admit the benefit accrued from hiring migrant workers. They paid visible minority female workers less than they would have to pay white U.S.-born house cleaners. Some of the employers insisted that they were only trying to help these poor disadvantaged women by giving them a job (Moras, 2010).
Turrittin, Hagey, Guruge, Collins \& Mitchelle (2002) argue that "democratic racism" operates in the latter part of the twentieth century, and is characterized by: lip service to equity, denial of racism in Canadian society, lack of accountability for advertently or inadvertently discounting people of colour, discourse of tolerance, and immunity from apology for white employers (p. 655). They are referring to the experiences of Black immigrant nurses in this study who were employed in various Canadian health agencies and/or hospitals. These authors are troubled by women's narratives that bring to light their supervisor's discourses of racism. For instance, the participants in this study reported discrimination at work with regards to their job responsibilities even though they had successfully acquired all the Canadian credentials and work experience needed for the job. Some of the nurses who were not being allowed to work in high-risk surgeries had higher credentials than the Canadian-born white nurses that routinely assisted at such surgeries. The issue here was not related to 'credentials', but rather, nurses experienced discrimination based upon simultaneous and interacting axes of race, immigrant status and gender. Risking further exclusion, the nurses asserted their agency and filed a Human Rights complaint. Their purpose was to "challenge racism practices, not on nationalist grounds, but rather out of concern for universal rights" (p.655). The point of this statement is that in Canadian post-modern, transnational, and global society, achieving equity based on minority status is no longer sufficient. If we want to attain social justice for all then we must tackle racism based on the premise that we are human beings rather than citizens who are given a certain identity and rights by the state.

\subsubsection{Adapting to the New Environment}

Given these challenging circumstances, how do these women learn to carry their double-load (market and domestic production)? This is the overarching question that guides Pio's (2005) work with universityeducated women migrants from India. Looking at Pio's sketch of participants' experiences on the New Zealand work terrain, their initial entry into the labour market is painted with bright colours of hope. Soon these colours change to dark shades of grey and black, symbolizing their demolished sense of self and feeling of worthlessness due to experiences of deskilling, devaluation, racism, and marginalization. His in-depth face-to-face interviews with participants suggest that, initially, these women resisted taking any job. Over time, they learnt to walk within the walls of Euro-centric 
workspaces. They showed great perseverance as they knocked on employers' doors with bleeding knuckles, spoke in spite of their accent until were heard, modified dress codes, reskilled, and started at the bottom (e.g., picking strawberries) as a way to gain some New Zealand work experience.

The colours on Pio's (2005) sketch change as he depicts the progress that participants are making from working as strawberry pickers or factory workers to achieving management positions and becoming entrepreneurs. These colours are neither grey nor black but neither are they as bright as those colours symbolizing women's expectations and hope in the early years of migration. Certainly these women's stories are not that different from other stories cited earlier. Unlike other researchers though, Pio (2005) is able to bring to the foreground the agency and resilience of women migrants.

In some way, Martins' (2007) study goals echo Pio's (2005). He interviewed South Asian women in Canada to hear about the strategies they used to adapt to the economic environment in a new country and how their occupational roles have changed post-migration. The participants in his study asserted that their first and most important occupational role was: wife, mother and caregiver. During the first two years, they experienced many economic hardships, like other migrants, and worked for economic efficiency. Like Zaman (2010), Martins (2007) found that the women whose husbands were able to find jobs in the initial years were selective about their choice of work. His findings highlight that "being able to maintain values from one's own cultural background" and forming friendships with people from the same cultural background emerged as vital contributing factors in these women's ability to adapt to a new economic, social, and political climate of the host country (p. 209). For example, when women were able to wear their cultural and/or religious dress, get guidance from people who were from the same cultural background, and maintain the occupational roles (such as that of a mother and wife) that they had in their country of origin, it eased their transition into the host society.

\section{STRENGTHS AND LIMITATIONS OF THE REVIEW}

As with all reviews, there are both strengths and limitations. Three strengths of the review include: 1 . Selection of studies as a step-by-step process. Though time consuming and tedious, this process systemically and methodically selected papers for inclusion; 2 .
Although it wasn't possible to include many studies from outside Canada, inclusion of some studies from Australia, and United States enhanced the review findings, and; 3 . The review was broad, but nevertheless, covered several topics in relation to employment from various disciplines including: Economics, Health/ Occupational Health, Sociology, Geography, Social Work, and Immigration Studies.

There were a number of limitations of the review, four of which follow: 1) The review was based on the primary author's interpretation. As a visible minority woman, selection and analysis of studies is coloured by the first author's biases and preferences; 2) While the review provided valuable information on employment experiences of women, due to space considerations, researchers' various epistemological positions (feminist, anti-racist, critical, and others), as well as their limitations and strengths were not discussed; 3 ) The quality of the review would have been enhanced through cross country evaluations (e.g., Canada and the United States), and; 4) The review covered literature only until 2011.

\section{GAPS IN LITERATURE}

Cross-sectional designs, a primary methodological tool in Census analysis, cannot provide a temporal analysis of women's employment experiences, such as long-term effects of deskilling. Longitudinal data is needed for this purpose. A further difficulty with Census data is that it is an analysis of the woman's paid work, ignoring the effect of unpaid employment status (e.g., domestic work, care giving, volunteer activities and the hidden economy) or other factors, such as poor working conditions, on women's labour force participation (Bancej, 1997). A more detailed evaluation of that considers both paid and unpaid work is important to gather a comprehensive understanding of employment experiences.

While quantitative studies on employment experiences of minority immigrants have provided useful information, more qualitative and mixed-methods work is essential research in order to understand the differential employment outcomes across various racial/ethnic groups in Canada. For example, while quantitative studies can quantify the prevalence of immigrant underemployment or unemployment. Participants' stories are needed to understand how culture intersects with gender to shape people's lives. More stories from the immigrant perspective will be helpful to find solutions to various problems that immigrants experience in their integration to Canada. 
Large-scale studies homogenized experiences of members of minority groups by pooling them together in the category "visible minority group". Limited studies that do exist on the settlement experiences of subgroups of the minority population are focused on South Asian and Chinese women, as these two groups constitute a growing proportion of immigrants to Canada (Statistics Canada, 2011). Nevertheless, from the context of providing ethnic specific services, it is essential to listen to voices of other subgroups of visible minority immigrant population, such as those from the Middle East, Africa, Philippines, etc.

Most reviewed papers pooled female refugee and immigrant participants together. It is commonly known that the pre-migration experiences of refugee women are often fraught with trauma related to war or natural disasters. Studies on refugee settlement experiences are needed to assist employment counsellors and social workers to adequately support them.

More studies are needed to understand the economic and social integration of sexual minority women. They may be vulnerable to racism at work, rendered invisible in society due to social policies that are predominantly heterosexual, and face prejudice within their cultural communities making their economic and social integration difficult.

Due to the growth in minority immigrant/refugee immigrant women in Canada's smaller urban and rural regions (Krahn, Derwing, \& Abu-Laban, 2005; WaltonRoberts, 2006, Sethi, 2009), there is a pressing need for the exploration of such settlement issues of visible minority immigrant/refugee women who settle in these communities. For example, in Grand Erie, an urbanrural region in Ontario, educated and skilled immigrant women residing in rural regions of Grand Erie experienced many difficulties, such as: lack of accessible transportation, child care issues, racism, etc. that made their economic and social integration very difficult (see Sethi, 2009).

\section{CONCLUSIONS \& IMPLICATIONS}

Of the 126 papers (includes quantitative, qualitative, and mixed-methods) that were analysed, four key findings include: 1) Economic welfare of immigrants continues to deteriorate with post-2000 arrivals facing much more occupational downward mobility than their previous cohort in the 1990's; 2) Gender, ethnicity and immigrant status intersects to shape visible minority women's employment experiences with foreign-born visible minority women experiencing more difficulty in the labor market than Canadian born visible minority women and white women; 3) Visible minority women experience discrimination due to their immigrant status; and, 4) Cultural barriers can impede visible minority women's economic progress.

In moving forward, it is important to recognize that immigrant visible minority women have needs that are different from immigrants in general. While progress has been made to foster immigrant integration, these programs neglect to take into account how gender intersects with ethnicity and immigrant status to marginalize visible minority women. For example, while the Federal Skilled Worker Program (Citizenship and Immigration Canada, [CIC] 2012) aims to foster integration of prospective skilled immigrants, men continue to outnumber women due to the stringent selection criterion based on language skills, education, work experience, adaptability and job offer in Canada. Women migrating from patriarchal cultures are often not given an opportunity to upgrade their human and capital skills required for successful economic integration in Canada.

It is encouraging to see that through the "Ontario Immigration Strategy" established by Michael Coteau, Ontario's Minister of Citizenship and Immigration, CIC is collaborating with employers and business leaders to reduce economic exclusion of immigrants and assist them in finding jobs that match their skills. The Minister has established the Ontario Award for Leadership in Immigration Employment to encourage employers/ business leaders to partake in this initiative (DeVoretz Canadian immigrant, 2013). It is also promising that the Ontario Human Rights Chief Commissioner, Barbara Hall, has demanded the removal of the Canadian experience barrier (Canadian Immigrant, 2013). However, it is not entirely clear how this policy will be enforced; for example, will employers be penalized for failing to adhere to the Ontario Human Rights code for demanding 'Canadian experience' as a prerequisite in job applications? Considering the surmountable evidence of deskilling in this thesis, the Office of the Fairness Commissioner and the Federal immigrant officials must collaborate so that there is a match between the pre-arrival message and the post-arrival reality. If the Canadian government is going to continue to recruit a skilled global labour force, then it is critical that federal officers who are responsible for recruiting skilled immigrants to Canada work with local employers and business to ensure immigrants/refugees fair access to employment and eliminate economic 
exclusion. Failure to do so will not only negatively impact their economic and social well-being into the host community but also impact Canada's overall economic productivity.

\section{REFERENCES}

A commitment to training and employment for women (2008). Retrieved September 30, 2010, from http://www.actew.org

Aydemir, A., \& Skuterud, M. (2005). Explaining the deteriorating entry earnings of Canada's mmigrant cohorts, 1966-2000. Canadian Journal of Urban Research, 12(2), 179-204. http://dx.doi.org/10.1111/j.0008-4085.2005.00297.x

Banerjee, R. (2009). Income growth of new immigrants in Canada: Evidence from the survey of labour and income dynamics. Relations Industrielles, 64(3), 466-488. http://dx.doi.org/10.7202/038552ar

Bancej, C. M. (1997). Immigrant women, work and health (M.Sc. Dissertation, McGill University, 1998). ProQuest Dissertations and Theses.(Publication Number: AAT MQ44122). Retrieved from http://proquest.umi.com/pqdweb? $\mathrm{did}=732033751 \& \mathrm{Fmt}=7 \&$ clientld $=27850 \& R Q T=309 \&$ VName $=\mathrm{PQD}$

Bartley, M., (1994). Unemployment and ill-health: understanding the relationship. Journal of Epidemiology and Community Health, 48, 333-337.

http://dx.doi.org/10.1136/jech.48.4.333

Bauder, H. (2003). Immigrants in urban labour markets: Place of birth and immigrant concentration in British Columbia. Canadian Journal of Urban Research, 12(2), 179-204.

Bloom, D. E., Grenier, G., \& Gunderson, M. (1994). The changing labor market position of Canadian immigrants. NBER Working Paper Series, Vol. w4672, 1994. Retrieved from http://www.nber.org/papers/w4672.pdf

Borjas, G. J. (1987). Immigrants, minorities, and labor market competition. Industrial and Labor Relations Review, 40(3), 382-392. http://dx.doi.org/10.1177/001979398704000305

Borjas, G. J. (1990). Friends or strangers: The impact of immigrants on the U.S. Economy. New York, NY: Basic Books.

Borjas, G. J. (1995). The economic benefits from immigration. Journal of Economic Perspectives, 9(2), 3-22. http://dx.doi.org/10.1257/jep.9.2.3

Borjas, G. J. (2003). The labor demand curve is downward sloping: Reexamining the impact of immigration on the labor market. Quarterly Journal of Economics, 118(4). http://dx.doi.org/10.1162/003355303322552810

Browne, I., \& Misra, J. (2003). The intersection of gender and race in the labor market. Annual Review of Sociology, 29, 487-513. doi: 10.1146/annurev.soc.29.010202.1

Buhr, K. J. (2010). Do immigrant nurses in Canada see a wage penalty? An empirical study. Business Economics, 45(3), 210-223. http://dx.doi.org/10.1057/be.2010.23

Canadian Immigrant. (2013). Remove "Canadian experience" barrier: Ontario Human Rights Commission. Retrieved from http://canadianimmigrant.ca/news-andviews/remove canadian-experience-barrier-ontario-human-rightscommission

Chiswick, B. R. (1978). Is the new immigration less skilled than the old? Journal of Labour Economics, 4(2), 168-192. http://dx.doi.org/10.1086/298099

Chui, T., \& Maheux, H. (2011). Visible minority women. (Catalogue no. 89-503-X). Retrieved from http://www.statcan.gc.ca/ pub/89-503-x/2010001/article/11527-eng.pdf

Citizenship and Immigration Canada. (2012). News release. Revised federal skilled worker program unveiled, Retrieved from http://www.cic.gc.ca/english/department/media/releases/201 2/2012-08-17.asp

Cobb-Clark, D., \& Crossley, T. F. (2001). Gender, comparative advantage and labor market activity in immigrant families. Labour Economics, 11(3), 373-393.

http://dx.doi.org/10.1016/j.labeco.2003.05.002

De Jong, G. F., \& Madamba, A. B. (2001). A double disadvantage? Minority group, immigrant status, and underemployment in the United States. Social Science Quarterly, 82(1), 117-130. http://dx.doi.org/10.1111/0038-4941.00011

DeVoretz, S. (2013). Ontario collaborating with employers to improve opportunities for immigrants. Retrieved from http://canadianimmigrant.ca/news-and-views/ontariocollaborating-withemployers-to-improve-opportunities-for-immigrants

Espiritu, Y. (1999). Gender and labor in Asian immigrant families. American Behavioral Scientist, 42(4), 628-647. http://dx.doi.org/10.1177/00027649921954390

Evans, S., \& Bowlby, S. (2000). Crossing boundaries: Racialized gendering and the labour market experiences of Pakistani migrant women in Britain. Women's Studies International Forum, 23(4), 461-474. http://dx.doi.org/10.1016/S0277-5395(00)00107-20

Gilmore, J. (2008). The Canadian immigrant labour market in 2006 : Analysis by region or country of birth. Catalogue no. 71-606X2008002, Labour Statistics Division, Statistics Canada. Retrieved from http://www.statcan.gc.ca/pub/71-606-x/71606-x2008002-eng.pdf

Grondin, C. (2005). Knowledge of official languages among new immigrants: How important is it in the labour market? Catalogue no. 89-624-XIE, Special Surveys Division. Retrieved from http://www.statcan.gc.ca/pub/89-624-x/89624-x2007000-eng.pdf

Guo, S. (2010). Understanding immigrants' downward social mobility: A comparative study of economic and social integration of recent Chinese immigrants in Calgary and Edmonton. Prairie Metropolis Centre Working Paper Series. Retrieved from http://teresawoopaw.ca/info/ESL_documents/Guo\%202010\% 20PMC\%20WP1012.pdf

Houle, R., \& Yssaad, L. (2010). Recognition of newcomers' foreign credentials and work experience, Perspectives, Statistics Canada-Catalogue no. 75-001-X. Retrieved from http://www.statcan.gc.ca/pub/75-001-x/2010109/pdf/11342eng.pdf

Hum, D., \& Simpson, W. (2010). The declining retirement prospects of immigrant men. Canadian Public Policy, 36(3), 287-305. http://dx.doi.org/10.1353/cpp.2010.0002

Iredale, R. (2005). Gender, immigration policies and accreditation: Valuing the skills of professional women migrants. Geoforum, 36, 155-166. http://dx.doi.org/10.1016/i.geoforum.2004.04.002

Krahn, H., Derwing, T., \& Abu-Laban, B. (2005). The retention of newcomers in second- and third-tier cities in Canada. International Migration Review, 39(4), 872-894. http://dx.doi.org/10.1111/j.1747-7379.2005.tb00292.x

Li, P. S. (2001). The market worth of immigrants' educational credentials. Canadian Public Policy/Analyse de Politiques, 27(1), 23-28. http://dx.doi.org/10.2307/3552371

Liu, E. N. (2006). Access to employment or access to employers: $A$ descriptive study of employers' attitudes and practices in hiring newcomer job seekers. (Master of Arts dissertation). Theses and dissertations. Paper 75. Retrieved from http://digitalcommons.ryerson.ca/cgi/viewcontent.cgi?article= 1076\&context=dissertations

Mahtani, M. (2004). Mapping race and gender in the academy: The experiences of women of colour faculty and graduate students in Britain, the U.S. and Canada. Journal of Geography in Higher Education, 28(1), 91- 99. http://dx.doi.org/10.1080/0309826042000198666 
Man, G. (2004). Gender, work and migration: Deskilling Chinese immigrant women in Canada. Women's Studies International Forum, 2, 135-148. http://dx.doi.org/10.1016/i.wsif.2004.06.004

Martins, V. \& Reid, D. (2007). New-immigrant women in urban Canada: insights into occupation and sociocultural context. Occupational Therapy International. 14(4), 203-220. http://dx.doi.org/10.1002/oti.233

Moras, A. (2010). Colour-blind discourses in paid domestic work: Foreignness and the delineation of alternative racial markers. Ethnic and Racial Studies, 33(2), 233-252. http://dx.doi.org/10.1080/01419870802604008

Oreopoulos, P. (2009). Why do skilled immigrants struggle in the labor market? A field experiment with six thousand résumés. Metropolis British Colombia Working Paper Series No. No. 09 -03. Retrieved from http://riim.metropolis.net/

Oxman-Martinez, J., Hanley, J., Lach, L., Khanlou, N., Weerasinghe, S., \& Agnew, V. (2005). Intersection of Canadian policy parameters affecting women with precarious immigration status: A baseline for understanding barriers to health. Journal of Immigrant Health, 7(4), 247-259.

http://dx.doi.org/10.1007/s10903-005-5122-2

Pendakur, K., \& Pendakur, R. (1998). Glass ceilings for ethnic minorities. Research on Immigration and Integration in the Metropolis. Working Paper Series, No. 05-27. Retrieved, August, 2011 from http://www.sfu.ca/ pendakur/pendakur_ and_pendakur_glass_ceiling.pdf

Pendakur, K., \& Pendakur, R. (2002). Colour my world: Have earnings gaps for Canadian-born ethnic minorities changed overtime? Canadian Public Policy, 28(4), 489-512. http://dx.doi.org/10.2307/3552211

Picot, G., Hou, F., \& Coulombe, S. (2007). Chronic low income and low income dynamics among recent immigrants. Catalogue no. 11F0019MIE2007294. Analytical Studies Branch Research Paper Series, no. 294. Retrieved from http://www.statcan.gc.ca/pub/11f0019m/11f0019m2007294eng.pdf

Picot, G., \& Sweetman, A. (2011) Why the Differences in Outcomes between Sweden and Canada? IZA Policy Paper No. 25. Retrieved from http://ftp.iza.org/pp25.pdf

Pio, E. (2005). Knotted strands: Working lives of Indian women migrants in New Zealand. Human Relations, 58, 1277-1299. http://dx.doi.org/10.1177/0018726705059858

Raghuram, P., \& Kofman, E. (2004). Out of Asia: Skilling, re-skilling and deskilling of female migrants. Women's Studies International Forum, 27(2), 95-100. http://dx.doi.org/10.1016/j.wsif.2004.06.001

Ralston, H. (1996). Canadian Immigration Policy in the Twentieth Century: Its Impact on South Asian Women. Canadian Woman Studies, 19 (3), 33-37.

Reitz, J. G. (2001). Immigrant skill utilization in the Canadian labour market: Implications of human capital research. Journal of International Migration and Integration, 2(3), 347-378. http://dx.doi.org/10.1007/s12134-001-1004-1

Reitz, J. G. (2007a). Immigrant employment success in Canada, part I: Individual and contextual causes. Journal of International Migration and Integration, 8(1), 11-36. http://dx.doi.org/10.1007/s12134-007-0001-4

Reitz, J. G. (2007b). Immigrant employment success in Canada, part II: Understanding the decline. Journal of International
Migration and Integration, 8(1), 37-62.

http://dx.doi.org/10.1007/s12134-007-0002-3

Reitz, J. G., \& Banerjee, R. (2007). Racial inequality, social cohesion, and policy issues in Canada. In T.J. Courchene, K. Banting, \& W. Wuttunee (Eds), Belonging? Diversity, recognition and shared citizenship in Canada. (pp. 489-545). Montreal, QC: Institute for Research on Public Policy. Retrieved from http://citeseerx.ist.psu.edu/viewdoc/ download?doi=10.1.1.111.202\&rep=rep1\&type=pdf

Saraswati, J. (2000). Poverty and visible minority women in Canada. Canadian Woman Studies. 20(3), 49-53.

Schmidt, C. (2010). Systemic discrimination as a barrier for immigrant teachers. Diaspora, Indigenous, and Minority Education, 4(4), 235-252. http://dx.doi.org/10.1080/15595692.2010.513246

Sethi, B. (2009). Exploring newcomer settlement and integration supports in Brantford, and Brant-Haldimand-Norfolk Counties: Community-based participatory research. Theses and Dissertations (Master of Social Work Thesis, Wilfred Laurier University, Canada). Paper 921. Retrieved from http://scholars.wlu.ca/etd/921

Shahrzad, M. (1999). De-skilling immigrant women. Canadian Woman Studies, 19(3), 123-128.

Statistics Canada. (2006). Women in Canada: A gender-based statistical report. (Catalogue no. 91-003-X). Social and Aboriginal Statistics Division. Retrieved from http://www. statcan.gc.ca/pub/89-503-x/89-503-x2005001-eng.pdf

Stelener, M. (2000). Earnings differentials among ethnic groups in Canada: A review of the research. Review of Social Economy, 58(3), 295-317. http://dx.doi.org/10.1080/00346760050132346

Syed, J., \& Pio, E. (2010). Veiled diversity? Workplace experiences of Muslim women in Australia. Asia Pacific Journal of Management, 27(1), 115-137. http://dx.doi.org/10.1007/s10490-009-9168-x

Turrittin, J., Hagey, R., Guruge, S., Collins, E., \& Mitchell, M. (2002). The experiences of professional nurses who have migrated to Canada: Cosmopolitan citizenship or democratic racism? International Journal of Nursing Studies, 39(6), 655-667. http://dx.doi.org/10.1016/S0020-7489(02)00003-2

Wald, S., \& Fang, T. (2008). Overeducated immigrants in the Canadian labour market: Evidence from the workplace and employee survey. Canadian Public Policy/Analyse De Politiques, 34(4), 457-479. http://dx.doi.org/10.3138/cpp.34.4.457

Walton-Roberts, M. (2006). Regional immigration and dispersal: Lessons from small and medium-sized urban centres in British Columbia. Our Diverse Cities, 2, 158-161. Retrieved from canada.metropolis.net/publications/.../our_diverse_ cities_vol2_en.pdf

Westhues, A., Ochocka, J., Jacobson, N., Simich, L., Maiter, S., Janzen, R., et al. (2008) Developing Theory From Complexity: Reflections on a Collaborative Mixed Method Participatory Action Research Study. Qualitative Health Research. 2008 18(5), 701-717.

http://dx.doi.org/10.1177/1049732308316531

Zaman (2010). Pakistani skilled/educated immigrant women in Canada: An exploratory study. Pakistan Journal of Women's Studies: Alam-e-Niswan, (17)2, 1-23.

Received on 06-08-2015

Accepted on 10-09-2015

Published on 31-12-2015

(C) 2015 Sethi and Williams; Licensee Lifescience Global.

This is an open access article licensed under the terms of the Creative Commons Attribution Non-Commercial License (http://creativecommons.org/licenses/by-nc/3.0/) which permits unrestricted, non-commercial use, distribution and reproduction in any medium, provided the work is properly cited. 